\title{
The Effectiveness of Learning Activities Based on Revised Bloom Taxonomy on Problem-Solving Ability
}

\author{
Dwi Wiranata $^{1 *}$, I Wayan Widiana ${ }^{2 *}$, Gede Wira Bayu ${ }^{3 *}$ (iD \\ 1,2,3 Pendidikan Dasar, Universitas Pendidikan Ganesha, Singaraja, Indonesia \\ *Corresponding author: dwiwiraata99@gmail.com ${ }^{1}$
}

\begin{abstract}
Abstrak
Rendahnya kemampuan pemecahan masalah siswa dikarenakan kurangnya aktivitas pembelajaran siswa, sehingga diperlukan aktivitas pembelajaran yang mampu memotivasi siswa untuk belajar dan mengembangkan kemampuan pemecahan masalah. Penilitian ini bertujuan untuk menganalisis efektivitas aktivitas pembelajaran berbasis Taksonomi Bloom Revisi terhadap kemampuan pemecahan masalah. Jenis penelitian yang digunakan yaitu penelitian pengembangan dengan model 4D. Subjek penelitian ini adalah yaitu 4 orang ahli dan 55 siswa kelas IV SD. Objek penelitian ini yaitu efektivitas aktivitas pembelajaran berorientasi Taksonomi Bloom Revisi. Metode pengumpulan data yang digunakan yaitu metode non-test dan metode tes. Instrumen yang digunakan berupa kuesioner dan tes uraian. Teknik analisis data yang digunakan yaitu teknik analisis data statistik deskriptif kuantitatif berupa uji prasyarat dan uji-t. Hasil penelitian ini menunjukkan bahwa rata-rata skor kelas eksperimen sebesar 83,50, sedangkan kelas kontrol sebesar 74,83, dan hasil uji-t memperoleh nilai signifikansi 0,969 dengan thitung sebesar 0,00 < tabel sebesar 0,05. Simpulan penelitian ini adalah aktivitas pembelajaran berbasis Taksonomi Bloom Revisi efektif untuk meningkatkan kemampuan pemecahan masalah siswa. Implikasi dari penelitian pengembangan ini adalah menghasilkan produk berupa aktivitas pembelajaran berbasi Taksonomi Bloom Revisi yang dapat melatih rasa ingin tahu, kepercayan diri dan meningkatkan kemampuan pemecahan masalah siswa.
\end{abstract}

Kata kunci: Kemampuan Pemecahan Masalah, Aktivitas Pembelajaran, Bloom Revisi

\section{Abstract}

The low problem-solving ability of students was due to the lack of student learning activities, so that learning activities were needed that can motivate students to learn and develop problem-solving skills. This study aimed to analyze the effectiveness of learning activities based on Revised Bloom's Taxonomy on problem-solving abilities. The type of research used was development research with a 4D model. The subjects of this study were four experts and 55 fourth-grade elementary school students. The object of this research was the effectiveness of Revised Bloom's Taxonomy-oriented learning activities. The data collection method used was the non-test method and the test method. The instruments used were questionnaires and description tests. The data analysis technique used was descriptive quantitative statistical data analysis techniques in the form of prerequisite tests and t-tests. The results of this study indicate that the average score of the experimental class was 83.50, while the control class was 74.83, and the t-test results obtained a significance value of 0.969 with an at-count of 0.00 $<\mathrm{t}$-table of 0.05 . This research concluded that learning activities based on Revised Bloom's Taxonomy effectively improve students' problem-solving abilities. The implication of this development research was to produce products in the form of learning activities based on Revised Bloom's Taxonomy that can train curiosity, self-confidence and improve students' problem-solving abilities.

Keywords: Problem Solving Ability, Learning Activities, Bloom Revisi

\begin{tabular}{|c|c|c|}
\hline History: & & Publisher: Undiksha Press \\
\hline Received & : March 19, 2021 & Licensed: This work is licensed under \\
\hline Revised & : March 21, 2021 & a Creative Commons Attribution 3.0 License \\
\hline Accepted & : June 10, 2021 & (c) (†) ( \\
\hline Published & : July 25, 2021 & (C) ${ }_{E Y}$ SA \\
\hline
\end{tabular}

\section{Introduction}

Skills in the 21st century require students to master problem-solving skills. Problemsolving ability is the ability of students to apply the knowledge they have, which is used to overcome the difficulties faced by students to achieve the expected goals (Malik, 2018; Popkova et al., 2019; Rusdin, 2018). The process of thinking in problem-solving is an important thing that needs to be paid attention to by educators, especially to help students develop their problem-solving skills well (Astra et al., 2020; Gholami et al., 2021; Öztürk et 
al., 2020). Improving students' problem-solving skills needs to be supported by appropriate learning methods to achieve learning objectives (Andriyani \& Suniasih, 2021; Choi et al., 2014; Phungsuk et al., 2017). As preparation to face challenges in the 21st century, the younger generation, especially students, must have problem-solving skills. These problemsolving abilities are needed so that students can compete globally (Manurung \& Panggabean, 2020; Setiyani et al., 2020).

The preliminary study showed that the low problem-solving ability of students was due to the lack of student learning activities carried out by fourth-grade teachers at SD Negeri 1 Banyuasri, Buleleng District, Buleleng Regency. Students in grade VI of the elementary school still do not understand the material in the book or what was explained by the teacher, especially in thematic learning. When carrying out the learning process, the teacher did not create a learning model useful for improving problem-solving skills. In addition, in the lecturing method, the teacher also used group division where this group division often reduces individual student activities. Students who were often active were more visible than students who were not active. That way, students did not understand how to solve the problems in thematic learning and cause students to be less active. Based on observations by giving pre-test questions conducted at the State Elementary School Number 1, Banyuasri showed that the students are less active in the learning process. Their learning activities tend not to increase. This is supported by the research, who found the same problem: the lack of learning activities caused students' problem-solving abilities to be reduced (Maharani \& Kartini, 2019; Sukmasari \& Rosana, 2017). When the teacher provides activities based on problem-solving in the form of questions or by experimenting, not all students can answer the question or experiment. When given the pre-test, only get an average score of 53.3, then the criteria are still low. To improve problem-solving skills, the solution that can be given is to develop learning activities oriented to the revised bloom taxonomy.

Learning activities are a process of behavior change that is very influential in ongoing learning (Apriandi, 2012; Sariayu \& Miaz, 2020; Widodo, 2014). In addition, learning activities can be interpreted as an activity that produces changes in knowledge and values of mental and emotional attitudes so that learning activities carried out are important indicators in learning (Noge, 2019; Risvanelli, 2017; Syawaluddin \& Iswari, 2015). The development of learning activities in this research collaborates with Revised Bloom's Taxonomy. Taxonomy is a special framework of thinking related to educational goals (Ardiani et al., 2013; Gunawan \& Palupi, 2012; Nurbaya et al., 2018). Revised Bloom's Taxonomy emphasizes education to design curriculum, assessment, and suitability between the two, namely curriculum and assessment. Therefore it is important to apply physical learning in formulating learning objectives (Juhanda, 2016; Nursa'adah et al., 2016; Sari et al., 2017). Bloom's Revised Taxonomy has two dimensions, namely knowledge, and cognitive dimensions. The knowledge dimension is divided into four, namely factual, conceptual, procedural, and metacognitive, while the cognitive process dimension consists of 6 dimensions, namely remembering $(\mathrm{C} 1)$, understanding $(\mathrm{C} 2)$, applying $(\mathrm{C} 3)$, analyze $(\mathrm{C} 4)$, evaluate (C5), and create (C6) (Effendi, 2017; Handayani, 2020; Netriwati, 2018). The advantage of using learning activities based on Revised Bloom's Taxonomy is that student activity is maximized, it will lead to adjustments for personal factors such as curiosity, goal structure, and student confidence about the problems given by the teacher and how to solve problems (Kurniasari, 2017; Ningsih, 2016; Suarmika \& Faliyandra, 2016). In addition, learning activities based on Revised Bloom's Taxonomy teach students to analyze concepts and methods that are suitable for solving problems, encourage students to think using the knowledge they have, and find the problems themselves so that students can solve the problems they face (Rosmalem, 2017; Sariayu \& Miaz, 2020; Wirawan, 2014). 
Several relevant studies supported this research. Firstly, the study that the picture and picture learning model can improve student learning activities in arts and culture subjects (Rosmalem, 2017). Second, the thematic learning in the perspective of Revised Bloom's Taxonomy could make the learning process more meaningful (Ardiani et al., 2013). Third, the development of HOTS-based teaching materials could improve problem-solving abilities in mathematics subjects (Anisah \& Lastuti, 2018; Hamdi et al., 2018; Pratama \& Retnawati, 2018). The purpose of this study was to analyze the effectiveness of learning activities based on Revised Bloom's Taxonomy on the problem-solving abilities of fourth-grade elementary school students in Cluster IV, Buleleng District, Buleleng Regency for the 2020/2021 Academic Year.

\section{Methods}

This research used a development research method with a 4D model. The 4D model consists of 4 stages, namely; (1) the definition stage (define); (2) the design stage; (3) stages of development (develop); (4) stages of dissemination. This research was conducted from April 2021 to May 2021. The first stage was the definition stage. An analysis of learning activities was carried out at this stage, prota and promissory analysis, and curriculum analysis. Then it was determined the theme that will be used in the learning activities in this study, taking theme 7 in class IV about the Beauty of Diversity in My Country. After carrying out the definition stage, followed by the second stage of design, several stages were carried out at this design stage, namely designing prototypes of learning-oriented activities, designing learning activities, and designing problem-solving knowledge questions. The activities developed to consist of 8 activities, namely the activity of applying factual knowledge, analyzing activity on factual knowledge, applying activity on conceptual knowledge, analyzing activity on conceptual knowledge, applying activity on procedural knowledge, analyzing activity on procedural knowledge, applying activity on metacognitive knowledge, analyzing activity on metacognitive knowledge. The third stage, namely the development stage, is carried out through three stages: the production, implementation, and evaluation stages. In the fourth stage, dissemination is carried out by providing learning activities to teachers. Then the data collection was carried out. The data from the results of giving the problem-solving knowledge test to the fourth elementary school students were the data after implementing the bloom revision taxonomy-oriented learning activity.

The subjects of this study were four experts and 55 fourth-grade elementary school students in the experimental class and the control class. The object of this research was the validation and effectiveness of Revised Bloom's Taxonomy-oriented learning activities. This research was conducted in SD Cluster IV, Buleleng District. From 6 elementary schools, only two schools were selected to be the sample, namely one school used for the experimental class and one school used for the control class. Based on the draw, the school that became the experimental class was chosen, namely SD Negeri 1 Banyuasri with a total of 16 male students and 12 female students, while the school selected as the control class was SD Negeri 4 Banyuasri with a total of 14 male students and 13 female students.

The data collection method used was the non-test method and the test method. The instrument was used in the form of a questionnaire and a description test. Before being distributed, a prerequisite test was carried out, namely validity and reliability tests. To test the validity of the content of learning activities, the result is 4.39 , while for the validation of the items of the problem-solving instrument, the result is 1 , and the reliability is 0.63 . The blueprint of the instrument for validation of the content of learning activities can be presented in Table 1. In Table 1, the blueprint of learning activity content validation instruments is presented, which consists of 16 items of assessment aspects given. As for the grid of the problem-solving knowledge test instrument, it can be presented in Table 2. 
Table 1. The Blueprint of Learning Activity Content Validity Instruments

\begin{tabular}{|c|c|c|}
\hline Aspect & No Item & Quantity \\
\hline Student-centered learning & 1,2 & 2 \\
\hline $\begin{array}{l}\text { Suitability of learning activities with the } \\
\text { dimensions of the goal }\end{array}$ & $3,4,5$ & 3 \\
\hline Making discoveries in learning & 6,7 & 2 \\
\hline $\begin{array}{l}\text { Learning activities enable students' } \\
\text { independence }\end{array}$ & 8,9 & 2 \\
\hline There are various uses of learning media & 10,11 & 2 \\
\hline Physical involvement in learning & 12,13 & 2 \\
\hline $\begin{array}{l}\text { There is social interaction in the } \\
\text { learning process }\end{array}$ & $14,15,16$ & 3 \\
\hline
\end{tabular}

Table 2. Blueprint of Problem-Solving Ability Instrument

\begin{tabular}{|c|c|c|c|c|c|}
\hline \multicolumn{2}{|r|}{ Basic Competence } & \multirow{2}{*}{$\begin{array}{l}\text { Question indicator } \\
\text { 1. Given a picture, } \\
\text { students can identify } \\
\text { the various diversity } \\
\text { of traditional houses. }\end{array}$} & \multirow{2}{*}{$\begin{array}{c}\begin{array}{c}\text { Cognitive } \\
\text { level }\end{array} \\
\mathrm{C} 3\end{array}$} & \multirow{2}{*}{$\begin{array}{c}\begin{array}{c}\text { Item } \\
\text { number }\end{array} \\
14, \text { and } \\
17\end{array}$} & \multirow{2}{*}{$\frac{\text { Quantity }}{2}$} \\
\hline 3.4 & $\begin{array}{l}\text { Identify } \\
\text { forms of ethnic, } \\
\text { social, and cultural } \\
\text { diversity in } \\
\text { Indonesia related to } \\
\text { unity and integrity }\end{array}$ & & & & \\
\hline 3.7 & $\begin{array}{l}\text { Explore new } \\
\text { knowledge } \\
\text { contained in the text }\end{array}$ & $\begin{array}{l}\text { 2. Presented non-fiction } \\
\text { text stories, students } \\
\text { can explore new } \\
\text { knowledge contained } \\
\text { in the text. }\end{array}$ & $\mathrm{C} 4$ & $\begin{array}{c}7,12 \text {, and } \\
19\end{array}$ & 3 \\
\hline 4.4 & $\begin{array}{l}\text { Conveying new } 3 . \\
\text { knowledge from } \\
\text { non-fiction texts into } \\
\text { writing in their } \\
\text { language }\end{array}$ & $\begin{array}{l}\text { Presented non-fiction } \\
\text { text stories, students } \\
\text { can convey new } \\
\text { knowledge that has } \\
\text { been obtained }\end{array}$ & $\mathrm{C} 3$ & $\begin{array}{c}8,13 \text { and } \\
18\end{array}$ & 3 \\
\hline 3.3 & $\begin{array}{l}\text { Identify various } 4 . \\
\text { types of forces, } \\
\text { including muscle } \\
\text { force, electric force, } \\
\text { magnetic force, } \\
\text { gravitational force. }\end{array}$ & $\begin{array}{l}\text { Given questions, } \\
\text { students can identify } \\
\text { muscle styles in } \\
\text { everyday life. }\end{array}$ & $\mathrm{C} 4$ & $\begin{array}{c}\text { 4, } 9 \text { and } \\
11\end{array}$ & 3 \\
\hline 4.3 & $\begin{array}{l}\text { Demonstrating the } 5 . \\
\text { benefits of force in } \\
\text { everyday life, for } \\
\text { example, muscle } \\
\text { force, electric force, } \\
\text { magnetic force, } \\
\text { gravitational force, } \\
\text { and frictional force. }\end{array}$ & $\begin{array}{l}\text { Given questions, } \\
\text { students can identify } \\
\text { electric forces in } \\
\text { everyday life }\end{array}$ & $\mathrm{C} 3$ & 2 and 3 & 2 \\
\hline 1.3 & $\begin{array}{l}\text { Identifying social, } 5 . \\
\text { economic, cultural, }\end{array}$ & $\begin{array}{l}\text { Presented with } \\
\text { pictures, students can }\end{array}$ & $\mathrm{C} 4$ & $\begin{array}{l}10 \text { and } \\
15\end{array}$ & 2 \\
\hline
\end{tabular}




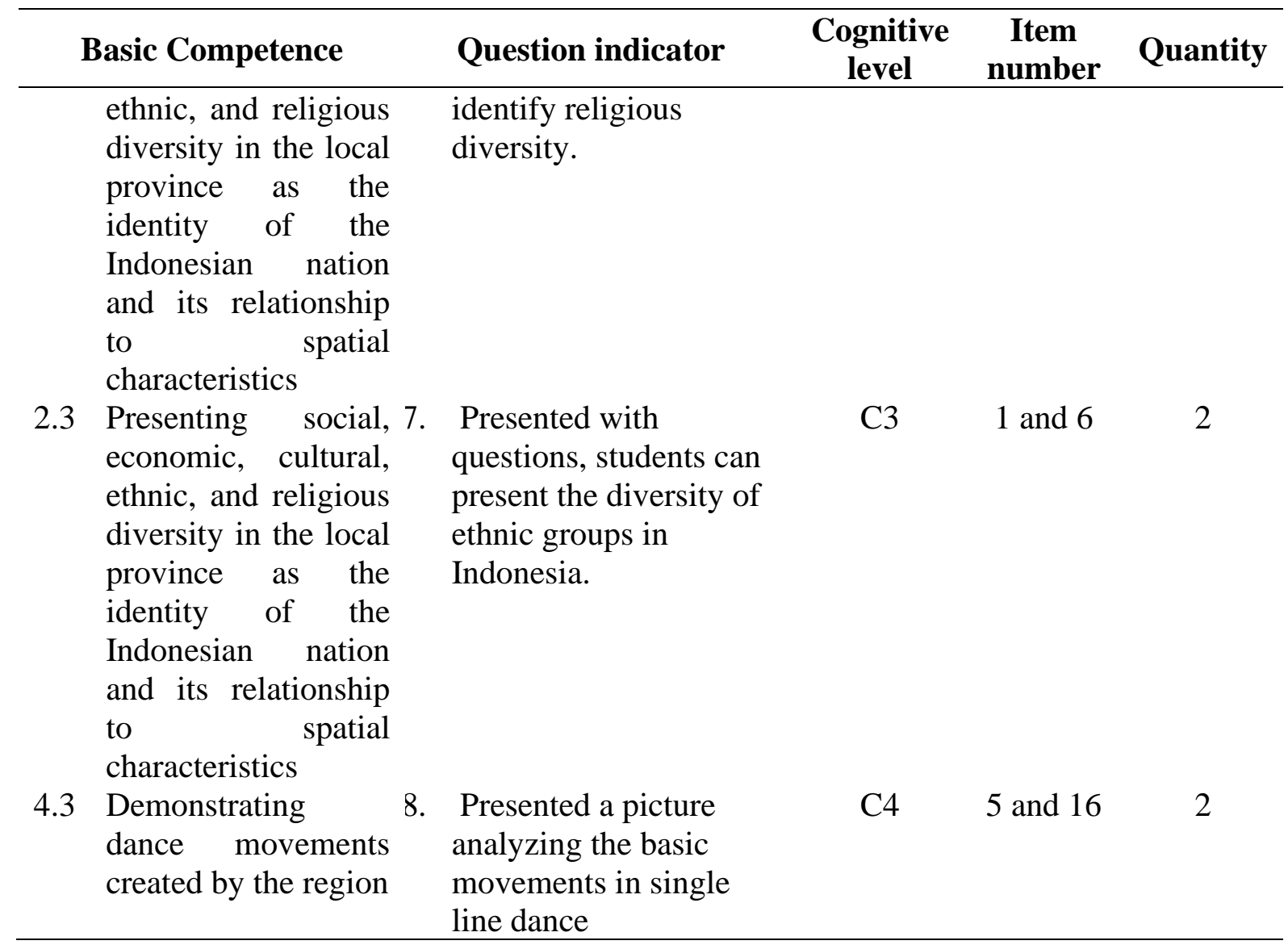

The data analysis technique used was descriptive quantitative statistical data analysis techniques in the form of prerequisite tests and t-tests. In this study, quantitative descriptive analysis was used to analyze the content validity of the developed learning activities and to analyze the average control class effectiveness scores and the average experimental class learning activities oriented to Revised Bloom's Taxonomy to improve students' problemsolving abilities.

\section{Results and Discussion \\ Results}

The results of the research conducted in the experimental class at SD Negeri 1 Banyuasri, which implemented learning activities based on Revised Bloom's Taxonomy, and in the control class at SD Negeri 4 Banyuasri who followed the conventional learning process, were given tests to determine students' problem-solving abilities. The recapitulation of the data calculation of the student's problem-solving knowledge test results can be presented in Table 3.

Table 3. Recapitulation of Data Calculation of Student Problem Solving Knowledge Test Results

\begin{tabular}{lcc}
\multicolumn{1}{c}{ Data } & \multicolumn{2}{c}{ Student Test Results } \\
& Experiment Class & Control Class \\
\hline Average & 83,50 & 74,84 \\
Standard Deviation & 5,34 & 5,82 \\
Highest Score & 95 & 85 \\
Lowest Score & 75 & 63 \\
Value Range & 20 & 22 \\
\hline
\end{tabular}


Based on Table 3, the average value in the experimental class is 83.50 , while the control class is 74.84 , the standard deviation of the experimental class is 5.337 , while the control class is 5.820, for the highest score of the experimental class is 95, while the control class is 85 , the score the lowest was in the experimental class, which was 75 , while the control class was 63 , for the range of values in the experimental class was 20, and the control class was 22. Thus, the group of students who participated in the learning process using Revised Bloom's Taxonomy-oriented learning activities (experimental class) had an average score of higher than the group of students without implementing Revised Bloom's Taxonomy-oriented learning activities (control class).

The results of the t-test obtained a significance value of 0.969 , with a tcount of 0.000 <ttable 0.05 , so there was a significant difference in scores between the control and experimental groups. So as the basis for decision making in the independent sample t-test, it can be concluded that $\mathrm{H} 0$ is rejected and $\mathrm{H} 1$ is accepted. So learning activities based on Revised Bloom's Taxonomy are effective for improving problem-solving skills. Furthermore, the results of this study are strengthened by research, showed that thematic learning in the perspective of Revised Bloom's Taxonomy could make the learning process more active and meaningful for students (Ardiani et al., 2013; Netriwati, 2018; Sari et al., 2017).

\section{Discussion}

The results of this research are learning activity products oriented to Revised Bloom's Taxonomy to improve the problem-solving ability of fourth-grade students. Learning activities are designed using an online learning system adapted to two dimensions in the Revised Bloom's Taxonomy, namely the cognitive process dimension and the knowledge dimension. Based on the results of the study, it appears that learning activities greatly affect problem-solving abilities, this is by the concept of learning activities which are a process of behavior change that is very influential in ongoing learning (Apriandi, 2012; Sariayu \& Miaz, 2020; Widodo, 2014). The use of learning activities to motivate students to enthusiastically participate in learning activities will have a good impact on problem-solving abilities (Choi et al., 2014; Dooren et al., 2019). This is supported by research, showed an increase in students' understanding of mathematical concepts by using activity sheets by students (Ningsih, 2016). Activities in this study combine with Revised Bloom's Taxonomy so that the activities provided are by the child's cognitive level and the achievement of the desired learning goals.

Learning activities based on Revised Bloom's Taxonomy can maximize the learning implementation process that can be adjusted to student ability. Thus, this is by the concept of Revised Bloom's Taxonomy, a special framework of thinking related to educational goals (Ardiani et al., 2013; Gunawan \& Palupi, 2012; Nurbaya et al., 2018). Learning activities based on the Revised Bloom's Taxonomy can motivate and train students' problem-solving skills. This is supported by a statement regarding the Revised Bloom's Taxonomy that there are two dimensions: knowledge and cognitive dimensions. The knowledge dimension is divided into 4, namely factual, conceptual, procedural, and metacognitive. In contrast, the cognitive process dimension consists of 6 dimensions, namely remembering (C1), understanding (C2), applying (C3), analyzing (C4), evaluating (C5), and creating (C6) (Effendi, 2017; Handayani, 2020; Netriwati, 2018).

The Revised Bloom's Taxonomy is the basic framework to improve students' understanding of the learning and teaching process (Gunawan \& Palupi, 2012; Radmehr \& Drake, 2018). Therefore, students' problem-solving abilities can be developed using learning activities based on Revised Bloom's Taxonomy. The difference in the results of the experimental group with the control group in this study was influenced by the advantages of using learning activities based on Revised Bloom's Taxonomy, namely maximum student activity, can lead to adjustments for personal factors such as curiosity, goal structure, and 
student confidence about the problems given by the teacher and how to solve problems (Kurniasari, 2017; Ningsih, 2016; Suarmika \& Faliyandra, 2016). This is in line with research on Revised Bloom's Taxonomy-based activities, which states that Revised Bloom's Taxonomy-based learning activities teach students to analyze concepts and methods that are suitable for solving problems, encourage students to think using the knowledge they have, and find the problem on their own so that students able to solve the problems encountered (Rosmalem, 2017; Sariayu \& Miaz, 2020; Wirawan, 2014).

This research is supported by several studies that are relevant to this research. Firstly research, showed that the picture and picture learning model could improve student learning activities in arts and culture subjects (Rosmalem, 2017). Second, research showed that thematic learning in the perspective of Revised Bloom's Taxonomy could make the learning process more meaningful (Ardiani et al., 2013). Third, research showed that the development of HOTS-based teaching materials could improve problem-solving abilities in mathematics subjects (Anisah \& Lastuti, 2018).

Based on the results and discussion, it can be concluded that learning activities based on the Revised Bloom's Taxonomy are effective for improving the problem-solving abilities of fourth-grade elementary school students in Cluster IV, Buleleng District, Buleleng Regency for the 2020/2021 Academic Year. Therefore, the implication of the implementation of this development research is to produce products in the form of learning activities based on Revised Bloom's Taxonomy that can train curiosity, self-confidence and improve the problem-solving abilities of fourth-grade elementary school students in Cluster IV, Buleleng District, Buleleng Regency for the 2020/2021 Academic Year.

\section{Conclusion}

The learning activities based on Revised Bloom's Taxonomy are effective for improving the problem-solving abilities of fourth-grade elementary school students in Cluster IV. Furthermore, this research suggests that teachers can implement learning activities based on Revised Bloom's Taxonomy well and can be used as solutions for implementing the learning process, especially to improve problem-solving abilities.

\section{References}

Andriyani, N. L., \& Suniasih, N. W. (2021). Development Of Learning Videos Based On Problem-Solving Characteristics Of Animals And Their Habitats Contain in Science Subjects On 6th-Grade. Journal of Education, 5(1), 37-47. https://doi.org/10.23887/jet.v5i1.32314

Anisah, \& Lastuti, S. (2018). Pengembangan Bahan Ajar berbasis HOTS untuk Meningkatkan Kemampuan Pemecahan Masalah Matematis Mahasiswa. Kreano: Jurnal Matematika Kreatif-Inovatif, 9(2), 191-197. https://doi.org/10.15294/kreano.v9i2.16341

Apriandi, D. (2012). Efektivitas Model Pembelajaran Kooperatif Tipe Two Stay-Two Stray (Ts-Ts) Dan Numbered Heads Together (Nht) Terhadap Prestasi Belajar Matematika Siswa Kelas Viii Smp Di Kabupaten Bantul Ditinjau Dari Aktivitas Belajar. Jurnal Ilmiah Pendidikan Matematika, 1(1). https://doi.org/10.25273/jipm.v1i1.467

Ardiani, N. F. W., Guna, N. A., \& Novitasari, R. (2013). Pembelajaran Tematik Dan Bermakna Dalam Perspektif Revisi Taksonomi Bloom. Satya Widya, 29(2), 93-107. https://doi.org/10.24246/j.sw.2013.v29.i2.p93-107

Astra, I. M., Raihanati, R., \& Mujayanah, N. (2020). Development of Electronic Module Using Creative Problem-Solving Model Equipped with Hots Problems on The Kinetic Theory of Gases Material. Jurnal Penelitian \& Pengembangan Pendidikan Fisika, 6(2), 181-194. https://doi.org/10.21009/1.06205 
Choi, E., Lindquist, R., \& Song, Y. (2014). Effects of problem-based learning vs. traditional lecture on Korean nursing students' critical thinking, problem-solving, and self-directed learning. Nurse Education Today, 34(1), 52-56. https://doi.org/10.1016/j.nedt.2013.02.012

Dooren, W. Van, Lem, S., Wortelaer, H. De, \& Verschaffel, L. (2019). Improving realistic word problem solving by using humorTitle. The Journal of Mathematical Behavior, 53. https://doi.org/10.1016/j.jmathb.2018.06.008

Effendi, R. (2017). Konsep Revisi Taksonomi Bloom Dan Implementasinya Pada Pelajaran Matematika SMP. JIPMAT: Jurnal Ilmiah Pendidikan Matematika, 2(1). https://doi.org/10.26877/jipmat.v2i1.1483

Gholami, M., Changaee, F., Karami, K., Shahsavaripour, Z., Veiskaramian, A., \& Birjandi, M. (2021). Effects of multiepisode case-based learning (CBL) on problem-solving ability and learning motivation of nursing students in an emergency care course. Journal of Professional Nursing, 37(3). https://doi.org/10.1016/j.profnurs.2021.02.010

Gunawan, I., \& Palupi, A. R. (2012). Taksonomi Bloom - Revisi Ranah Kognitif: Kerangka Landasan Untuk Pembelajaran, Pengajaran, Dan Penilaian. Premiere Educandum: Jurnal Pendidikan Dasar Dan Pembelajaran, 2(2). https://doi.org/10.25273/pe.v2i02.50

Hamdi, S., Suganda, I. A., \& Hayati, N. (2018). Developing higher-order thinking skill (HOTS) test instrument using Lombok local cultures as contexts for junior secondary school mathematics. Research and Evaluation in Education, 4(2), 126-135. https://doi.org/10.21831/reid.v4i2.22089

Handayani, N. N. L. (2020). Taksonomi Bloom Revisi Ranah Kognitif (Kerangka Landasan Untuk Pembelajaran, Pengajaran, Dan Penilaian). Widyacarya: Jurnal Pendidikan, Agama Dan Budaya, 4(2). http://doi.org/10.25273/pe.v2i02.50

Juhanda, A. (2016). Analisis Soal Jenjang Kognitif Taksonomi Bloom Revisi Pada Buku Sekolah Elektronik (BSE) Biologi SMA. Jurnal Pengajaran MIPA, 21(1), 61-66. https://doi.org/10.18269/jpmipa.v21i1.657

Kurniasari, F. (2017). Implementasi Pendekatan Saintifik Pada Penugasan Aktivitas Di Buku Teks Bahasa Indonesia Kelas VII SMP Berdasarkan Kurikulum 2013. Jurnal Pendidikan Edutama, 4(1), 9-26. https://doi.org/10.30734/jpe.v4i1.44

Maharani, N., \& Kartini, K. S. (2019). Penggunaan google classroom sebagai pengembangan kelas virtual dalam keterampilan pemecahan masalah topik kinematika pada mahasiswa jurusan sistem komputer. PENDIPA Journal of Science Education, 3(3), 167-173. https://doi.org/10.33369/pendipa.3.3.167-173

Malik, R. S. (2018). Educational Challenges in 21st Century and Sutainable Development. Journal of Sustainable Development Education and Research, 2(1), 9-20. https://doi.org/10.17509/jsder.v2i1.12266

Manurung, \& Panggabean. (2020). Improving Students' Thinking Ability In Physics Using Interactive Multimedia Based Problem Solving. Cakrawala Pendidikan, 39(2), 460-470. https://doi.org/10.21831/cp.v39i2.28205

Netriwati, N. (2018). Penerapan Taksonomi Bloom Revisi untuk Meningkatkan Kemampuan Pemahaman Konsep Matematis. Desimal: Jurnal Matematika, 1(3). https://doi.org/10.24042/djm.v1i3.3238

Ningsih, Y. L. (2016). Kemampuan Pemahaman Konsep Matematika Mahasiswa Melalui Penerapan Lembar Aktivitas Mahasiswa (LAM) Berbasis Teori APOS Pada Materi Turunan. Edumatica, 6(1), 1-8. https://doi.org/10.1063/1.4944618

Noge, M. D. (2019). Penerapan Model Pembelajaran Bilingual Preview-Review Berbasis EFlashcard Untuk Meningkatkan Aktivitas Dan Prestasi Belajar Bahasa Inggris Siswa $\begin{array}{lllll}\text { Smp. Journal of Education } & \text { Technology, } & \text { 2(1), }\end{array}$ https://doi.org/10.23887/jet.v2i1.13801 
Nurbaya, S., Rahman, F., Rustono, \& Subyantoro. (2018). Pengaruh Skemata Terhadap Kompetensi Membaca Pemahaman Berbasis Taksonomi Ruddell. LITERA, 17(1), 5969. https://doi.org/10.1177/0011000099273004

Nursa'adah, E., Kurniawati, D., \& Yunita, Y. (2016). Analisis Kemampuan Kognitif Mahasiswa pada Konsep Asam-Basa Menggunakan Tes Berdasarkan Taksonomi Bloom Revisi. EduChemia: Jurnal Kimia Dan Pendidikan, 1(1). http://dx.doi.org/10.30870/educhemia.v1i1.437

Öztürk, M., Akkan, Y., \& Kaplan, A. (2020). Reading comprehension, Mathematics selfefficacy perception, and Mathematics attitude as correlates of students' non-routine Mathematics problem-solving skills in Turkey. International Journal of Mathematical Education in Science and Technology, 51(7), 1042-1058. https://doi.org/10.1080/0020739X.2019.1648893

Phungsuk, R., Viriyavejakul, C., \& Ratanaolarn, T. (2017). Development of a problem-based learning model via a virtual learning environment. Kasetsart Journal of Social Sciences, 38(3), 297-306. https://doi.org/10.1016/j.kjss.2017.01.001

Popkova, E. G., Ragulina, Y. V, \& Bogoviz, A. V. (2019). Industry 4.0: Industrial Revolution of the 21st Century. https://doi.org/10.1007/978-3-319-94310-7

Pratama, G. S., \& Retnawati, H. (2018). Urgency of Higher Order Thinking Skills (HOTS) Content Analysis in Mathematics Textbook. Journal of Physics: Conference Series, 1097(1). https://doi.org/10.1088/1742-6596/1097/1/012147

Radmehr, F., \& Drake, M. (2018). An assessment-based model for exploring the solving of mathematical problems: Utilizing revised bloom's taxonomy and facets of

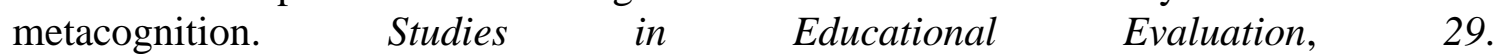
https://doi.org/10.1016/j.stueduc.2018.02.004

Risvanelli. (2017). Peningkatan Hasil Belajar dan Aktivitas Siswa Kelas V Menggunakan Pendekatan Value Clarification Technique (VCT) Pada Pembelajaran PKn di SDN 24 Batang Anai Kabupaten Padang Pariaman. JPPI (Jurnal Penelitian Pendidikan Indonesia), 3(2), 44-56. https://doi.org/10.29210/02017116

Rosmalem. (2017). Peningkatan Aktivitas Belajar Siswa Dengan Model Pembelajaran Picture And Picture Pada Pelajaran Seni Budaya. Jurnal Handayani: Jurnal Kajian Pendidikan Pra Sekolah Dan Pendidikan Dasar, 6(2), 153-161. https://doi.org/10.24114/jh.v6i2.6529

Rusdin, N. M. (2018). Teachers' Readiness in Implementing 21st Century Learning. International Journal of Academic Research in Business and Social Sciences, 8(4), 1271-1284. https://doi.org/10.6007/ijarbss/v8-i4/4270

Sari, R. Y., Netriwati, N., \& Sari, F. I. (2017). Pengaruh Model Pembelajaran Attention, Relevance, Confidence and Satisfaction (ARCS) terhadap Kemampuan Berpikir Matematis berdasarkan Taksonomi Bloom Revisi. Numerical: Jurnal Matematika Dan Pendidikan Matematika, 1(1). https://doi.org/10.25217/numerical.v1i1.119

Sariayu, M. R., \& Miaz, Y. (2020). Peningkatan Aktivitas Belajar Siswa Melalui Model Think Pair Share di Sekolah Dasar. Jurnal Basicedu, 4(2), 295-305. https://doi.org/10.31004/basicedu.v4i2.337

Setiyani, S., Fitriyani, N., \& Sagita, L. (2020). Improving student's mathematical problem solving skills through Quizizz. JRAMathEdu (Journal of Research and Advances in Mathematics Education), $\quad$ 5(3), 276-288. https://doi.org/10.23917/jramathedu.v5i3.10696

Suarmika, P. E., \& Faliyandra, F. (2016). Model Kooperatif GI Berbasis Outdoor Study Meningkatkan Aktivitas dan Hasil Belajar IPA SD. JPDI (Jurnal Pendidikan Dasar Indonesia), 1(2), 20-24. https://doi.org/10.26737/jpdi.v1i2.261

Sukmasari, V. P., \& Rosana, D. (2017). Pengembangan penilaian proyek pembelajaran IPA 
berbasis discovery learning untuk mengukur keterampilan pemecahan masalah. Jurnal Inovasi Pendidikan IPA, 3(1), 101-110. https://doi.org/10.21831/jipi.v3i1.10468

Syawaluddin, \& Iswari, M. (2015). Penerapan Model Pembelajaran Saintifik untuk Meningkatkan Aktivitas dan Hasil Belajar enerapan Model Pembelajaran Saintifik untukMeningkatkan Aktivitas dan Hasil Belajar Bahasa Inggris Topik Prosedur Teks Kelas IX SMP. Jurnal Konseling Dan Pendidikan, 2(1), 55-61. https://doi.org/10.31004/obsesi.v3i1.136

Widodo. (2014). Strategi Peningkatan Aktivitas Jasmani Siswa Sekolah Dasar di Luar Pembelajaran Pendidikan Jasmani, Olahraga, dan Kesehatan di Indonesia. Jurnal Pendidikan Dan Kebudayaan, 20(2), 281-294. https://doi.org/10.24832/jpnk.v20i2.144

Wirawan, Y. R. (2014). Pengaruh Penggunaan Model Pembelajaran Talking Stick Terhadap Aktivitas Belajar Dan Hasil Belajar Pada Mata Pelajaran Ekonomi Kelas X Di Sma Negeri Bandarkedungmulyo Jombang Tahun Ajaran 2012/2013. Equilibrium, 2(2), 124135. http://doi.org/10.25273/equilibrium.v2i2.632 